\title{
Achradina pulchra, a Unique Dinoflagellate (Amphilothales, Dinophyceae) with a Radiolarian-like Endoskeleton of Celestite (Strontium Sulfate)
}

\author{
Fernando GÓMEZ ${ }^{1}$, Konstadinos KIRIAKOULAKIS ${ }^{2}$, Enrique LARA ${ }^{3}$ \\ ${ }^{1}$ Carmen Campos Panisse 3, Puerto de Santa María, Spain; ${ }^{2}$ Faculty of Science, School of Natural Sciences and Psychology, \\ Liverpool John Moores University, Liverpool, United Kingdom; ${ }^{3}$ Real Jardín Botánico, CSIC, Madrid, Spain
}

\begin{abstract}
We examined the planktonic dinoflagellate Achradina pulchra by light and scanning electron microscopies from the South and North Atlantic oceans. The basket-like skeleton has been interpreted as a thick cell covering or pellicle of organic composition, or as a siliceous endoskeleton. The skeleton of Achradina is known only from fresh material, being absent in preserved samples, sediments or the fossil record. X-ray microanalysis revealed that the endoskeleton of Achradina is composed of celestite (strontium sulfate) with traces of barite (barium sulfate), two minerals that readily dissolve after cell death. To date, Acantharia and polycystine radiolarians (Retaria) were the only known organisms with a skeleton of this composition. We can now add a dinoflagellate to the list of such mineralized skeletons, which influence on the biogeochemical fluxes of strontium and barium in the oceans. Moreover, we provided the first molecular data for a skeleton-bearing dinoflagellate. Molecular phylogeny based on the SSU rRNA gene sequences revealed that Achradina and several environmental clones branched as an independent lineage within the short-branching dinokaryotic dinoflagellates. To date, seven clades of dinokaryotic dinoflagellates are known living as symbionts in the endoplasm of Acantharia and polycystine radiolarians. Because celestite built skeletons were unknown outside radiolarians, we suggested that the ancestors of Achradina acquired the genes implicated in the deposition of strontium and barium from radiolarian hosts though a horizontal gene transfer event between microbial eukaryotes.
\end{abstract}

Key words: Acantharea, Amphilothus, barite, celestite skeleton, Dinoflagellata, endosymbiosis, gene transfer, plankton symbiosis, Retaria

\section{INTRODUCTION}

Dinoflagellates possess several remarkable ultrastructural and genetic features that distinguish them from other eukaryotes; such features include a very particular nucleus with permanently condensed chromatin (the dinokaryon) and a huge genome. Dinoflagellate

Address for correspondence: Fernando Gómez, Carmen Campos Panisse 3, E-11500 Puerto de Santa María, Spain; E-mail: fernando. gomez@fitoplancton.com biology and genome evolution have been fundamentally influenced by the frequent transfer of individual genes and large-scale transfer of genes (Lin 2011, Wisecaver and Hackett 2011). Only a handful of dinoflagellate species with a mineral skeleton are known: Actiniscus pentasterias, Dicroerisma psilonereiella, Monaster, Amphilothus and Achradina (Sournia 1986, Fensome et al. 1993). Among other features, the presence of an endoskeleton was used to suggest a phylogenetical relationship between radiolarians and dinoflagellates (Hollande et al. 1962). Achradina pulchra, 
known from warm seas, possesses a basket-like skeleton which composition has been matter of speculation for a century. Some authors have considered it as an exoskeleton of organic composition, and an opening or window in the skeleton has even been compared to an archeopyle, or excystment opening (HernándezBecerril and Bravo-Sierra 2004). Other authors have considered the skeleton to be siliceous (Taylor 1987). However, it is striking that the skeleton of Achradina has never been reported from sediments and the fossil record. This suggested that the skeletons are not preserved after the cell's death, and are thus probably not composed of silica. In the present study, we solve the controversy over the composition of the skeleton with the aid of X-ray microanalysis. We provide the first molecular data from a dinoflagellate with a mineral skeleton, and propose a hypothesis for the evolutionary origin of the skeleton.

\section{MATERIALS AND METHODS}

\section{Sampling and microscopy}

Sampling was carried out in April 2013 in the São Sebastião

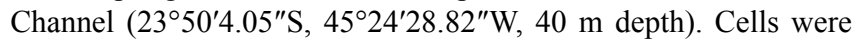
collected using a phytoplankton net ( $20 \mu \mathrm{m}$ mesh size $)$ in surface waters. The living, concentrated samples were examined in Utermöhl chambers at a magnification of $\times 200$ with an inverted microscope [Diaphot-300 (Nikon Inc., Tokyo, Japan)], and photographed with a digital camera (Cyber-shot DSC-W300; Sony, Tokyo, Japan) mounted on the microscope's eyepiece.

\section{Scanning electron microscopy (SEM) and X-ray en- ergy dispersive spectroscopy (EDS)}

The cells were obtained during a biogeochemical study of particulate organic matter in the water column over two seamounts in the northeastern Atlantic Ocean (Seine Seamount; $33^{\circ} 46^{\prime} \mathrm{N}$, $14^{\circ} 21^{\prime} \mathrm{W}$ and Sedlo Seamount; $40^{\circ} 19^{\prime} \mathrm{N}, 26^{\circ} 40^{\prime} \mathrm{W}$; see also Kiriakoulakis et al. 2009). We illustrated some of the cells from selected samples collected at $50 \mathrm{~m}$ depth in November 2003 (FS Meteor cruise \#60/1), March 2004 (FS Poseidon cruise \#309) and July 2004 (Discovery cruise \#282). Suspended particulate material was collected on large (290 mm diameter) glass-fibre filters (GF/F, Whatman, Brentford, UK) using large-volume in situ pumps. The filters were initially stored at $-80^{\circ} \mathrm{C}$ and then freeze-dried until further analysis in the lab could be carried out. Punched circles $\left(\sim 133 \mathrm{~mm}^{2}\right)$ of selected filters were glued to stubs, sputter-coated with $60 \%$ gold/palladium and viewed using a scanning electron microscope (Philips XL30, Eindhoven, The Netherlands) equipped with an energy-dispersive X-ray spectrometer (Voyager, Noran Instruments, Middleton, WI, USA) operated at $15 \mathrm{kV}$. X-ray energy dispersive spectroscopy (EDS) was used for qualitative chemical analyses of the skeletons.

\section{PCR amplification, cloning and DNA sequencing}

Cells of Achradina pulchra for molecular analysis were collected from surface waters in the middle of the São Sebastião Channel in April 22, 2013. Each cell was micropipetted with a fine capillary into a clean chamber and washed several times in serial drops of $0.2 \mu \mathrm{m}$ filtered and sterilized sea water. Finally, five cells were deposited in a $0.2 \mathrm{ml}$ Eppendorf tube filled with several drops of absolute ethanol. The sample was kept at room temperature and in darkness until the molecular analysis could be performed. The sample was centrifuged for $5 \mathrm{~min}$ at $504 \mathrm{~g}$. The ethanol was then evaporated in a vacuum desiccator and the cells were resuspended directly in $25 \mu \mathrm{l}$ of GoTaq PCR buffer (Promega, Lyon, France). PCRs were done in a reaction mix containing the eukaryotic-specific SSU rDNA primers EK-42F (5'-CTCAARGAYTAAGCCATGCA-3') and EK-1520R (5'-CYGCAGGTTCACCTAC-3') (López-García et al. 2001). PCRs were performed under the following conditions: 3 min denaturation at $95^{\circ} \mathrm{C}$; then 45 cycles with denaturation at $95^{\circ} \mathrm{C}$ for $15 \mathrm{~s}$, annealing at $50^{\circ} \mathrm{C}$ for $30 \mathrm{~s}$ and extension at $72^{\circ} \mathrm{C}$ for $2 \mathrm{~min}$; final extension at $72^{\circ} \mathrm{C}$ for $7 \mathrm{~min}$. A nested PCR was then carried out using $2 \mu \mathrm{L}$ of the first PCR products in a GoTaq polymerase reaction mix containing the eukaryotic-specific primers EK-82F (5'-GAAACTGCGAATGGCTC-3') and EK-1498R (5'-CACCTACGGAAACCTTGTTA-3') (López-García et al. 2001, Lara et al. 2011) and similar PCR conditions as described above, except for the annealing temperature of $55^{\circ} \mathrm{C}$ (instead of $50^{\circ} \mathrm{C}$ ) and 40 cycles (instead of 45 cycles). Amplicons of the expected size ( $\sim 1700$ base pairs) were cloned using a PCR2.1 Topo TA Cloning system (Invitrogen, Life Technologies, Saint Aubin, France) following the instructions provided by the manufacturer. Cloned products were sequenced using primers situated on the vector. Amplicons of the expected size were fully sequenced using a BigDye197 Terminator Cycle Sequencing Ready Reaction Kit (Applied Biosystems, Foster City, CA, USA) and analysed with an ABI-3130XL DNA sequencer (Applied Biosystems).

\section{Phylogenetic analyses}

The three new SSU rDNA sequences were aligned to a multiple sequence alignment containing a diverse set of 58 dinokaryotic dinoflagellate sequences using the profile alignment option of MUSCLE 3.7 (Edgar 2004), with the aim of including species of all mutualist symbiotic dinokaryotes in polycystine radiolarians for which sequences were available (Gast and Caron 1996, 2001; Dolven et al. 2007, Yuasa et al. 2016). Decelle et al. (2012) reported sequences of dinokaryotic dinoflagellates isolated from an acantharian species, which branched into the clades of Azadinium, Heterocapsa, Scrippsiella and Pelagodinium. Their sequences were too short to be included in our alignment. However, these clades were presented with other complete sequences of these four genera. The sequences of the syndinean dinoflagellates Hematodinium (EF065717) and Syndinium (DQ146404), as well as one related environmental clone (KJ761049), were used as outgroups. The resulting alignment was manually inspected using the program BioEdit 7.1.11 (Hall 1999). Ambiguously aligned regions and gaps were excluded in phylogenetic analyses. A phylogenetic tree was constructed using a RAxML model where nodes were evaluated by rapid bootstrapping (Stamatakis et al. 2008) as computed in the CIPRES phylogenetic portal (Miller et al. 2010). The proportion of invariable sites was estimated. The newly-generated sequences were deposited in DDBJ/EMBL/ GenBank under accession numbers MF543363-MF5433635. 


\section{RESULTS}

We obtained the SSU rDNA sequences of several clones from a sample with five cells of Achradina pulchra isolated on April 22, 2013 at São Sebastião Channel in Brazil (Figs 1A-B). The cell covering easily lysed due to the manipulation. The skeleton was an internal structure (Figs 1C-D). In the observations by scanning electron microscopy, the cells were devoid of cell covering and cytoplasm, and thus only the endoskeleton remained (Figs. 1E-G). The endoskeleton was a basket-like structure with a tessellation of irregular polygons. We examined the chemical composition of the endoskeleton using X-ray energy dispersive spectros- copy (EDS). The X-ray EDS spectrum showed a strong peak of strontium, and two secondary peaks of sulfur and oxygen (Fig. 1H). There were several consecutive small peaks of barium. Other peaks corresponded to chloride, sodium, magnesium and potassium, major constituents of sea water salts. Consequently, the major composition of endoskeleton is a mineral composed of strontium, sulfur and oxygen, plus small fractions of barium (Fig. 1H). These elements corresponded to the composition of celestite (strontium sulfate, $\mathrm{SrSO}_{4}$ ) with traces of barite (barium sulfate, $\mathrm{BaSO}_{4}$ ).

We examined the phylogenetic position of Achradi$n a$ with respect to a variety of dinoflagellate SSU rRNA gene sequences, with an especial focus on available
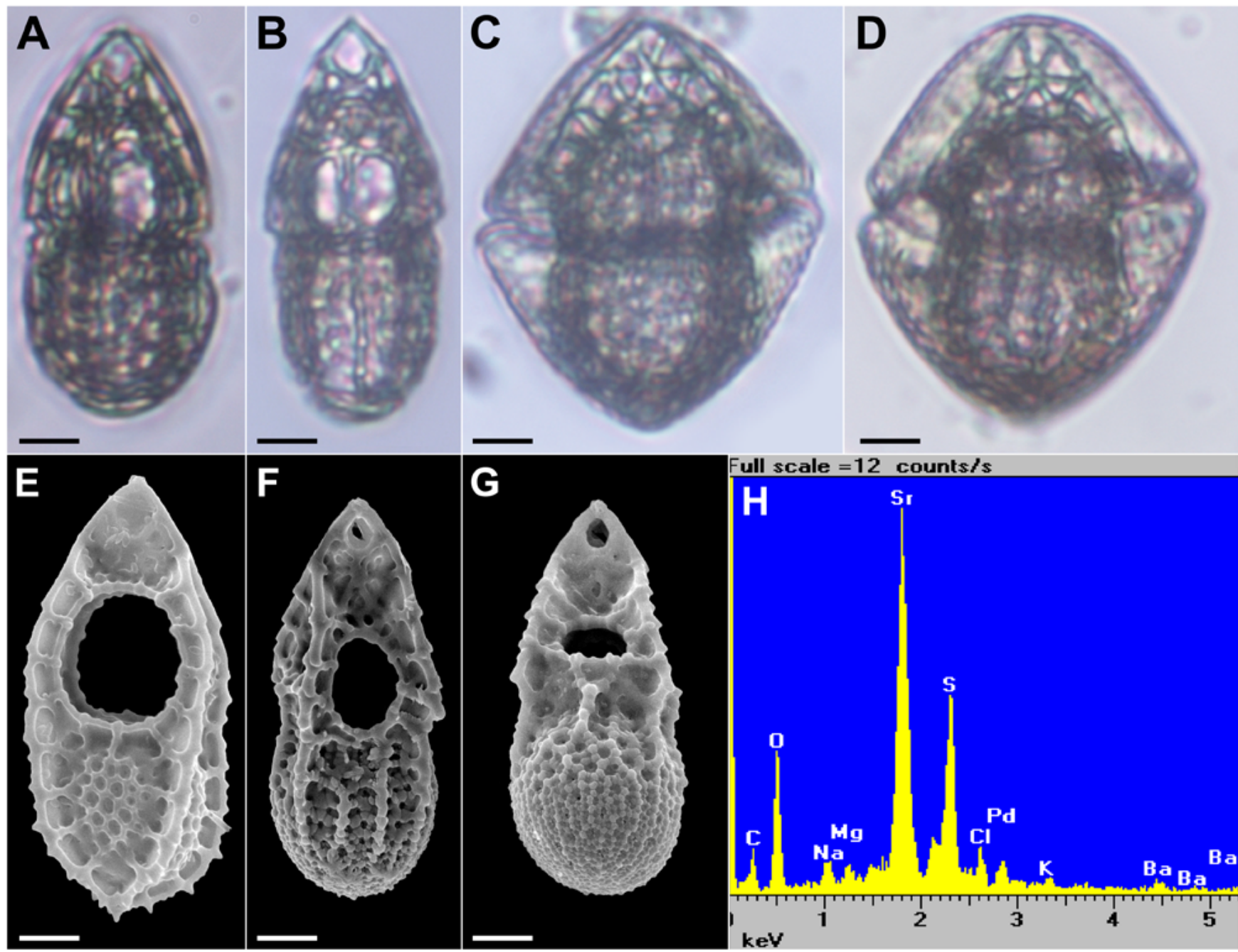

Figs 1A-H. Achradina pulchra. A-B - Light micrographs of the isolated cells of Achradina pulchra for PCR analysis from the SW Atlantic (São Sebastião Channel). C-D - Other cells from the same sample. Note that the skeleton is internal. E-G - Scanning electron micrographs of the skeleton from the NE Atlantic (Seine and Sedlo Seamounts). H - X-ray energy dispersive spectroscopy (EDS) spectrum of the endoskeleton. Scale bars: $5 \mu \mathrm{m}$. 


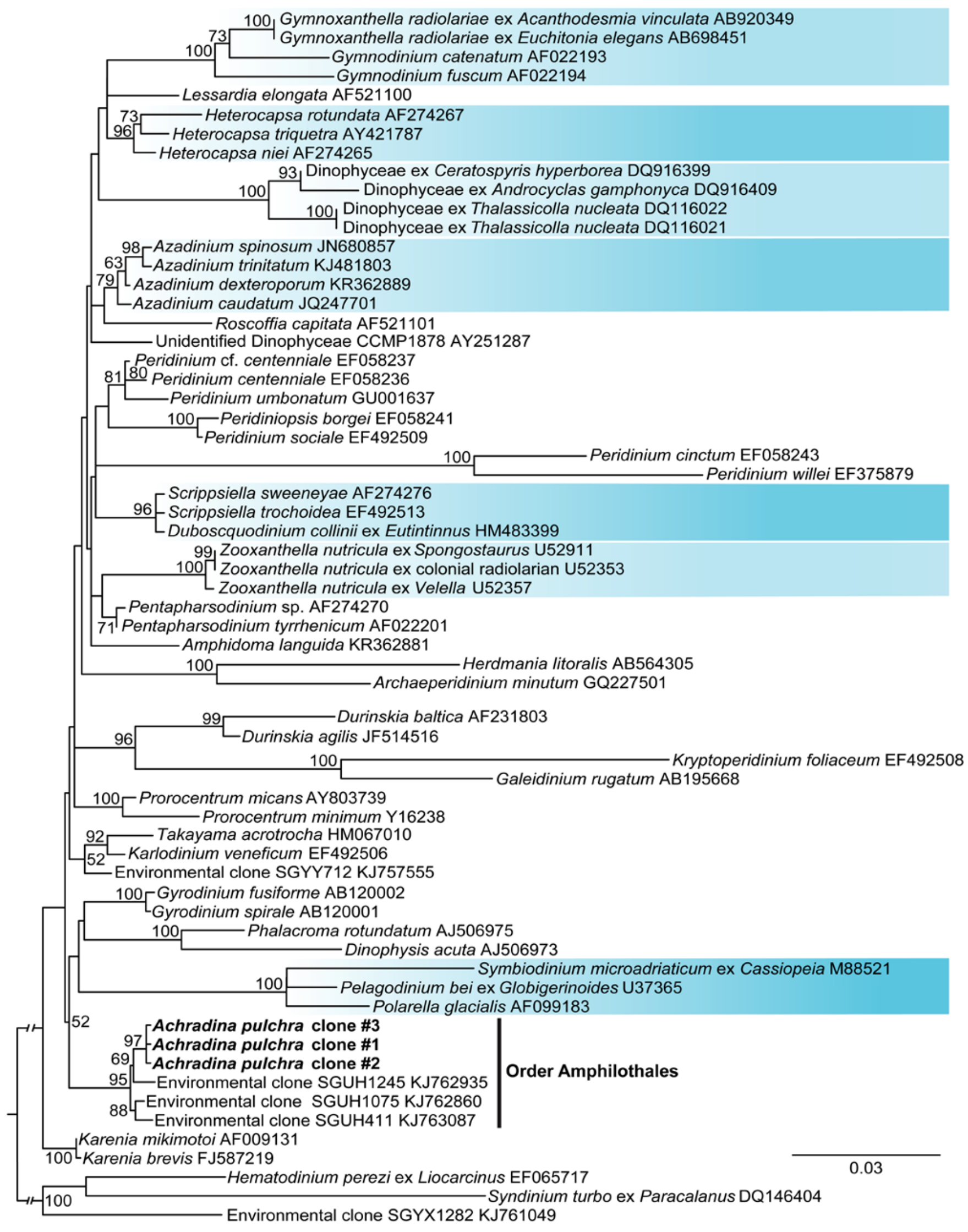


sequences of symbiotic dinoflagellates and sequences of dinoflagellates retrieved from PCR amplifications of acantharian and polycystine radiolarian cells (Fig. 2 ). The clade formed by Achradina and three environmental clones is robustly supported (bootstrap value of $95 \%$ ). It constituted a novel clade that branched within the large lineage comprising Gymnodiniales, Peridiniales, Dinophysales and Prorocentrales but with poor support, making it difficult to infer its affinity with known dinoflagellates. The dinokaryotic dinoflagellates isolated from acantharian and polycystine radiolarian hosts branched into seven different clades, which were not whatsoever related to Achradina (Fig. 2).

\section{DISCUSSION}

To date, only spicules of Acantharia, central capsules of vegetative adults of polycystine radiolarians, and the membrane-bound vesicles of their bi-flagellated swarmers were known to be built with celestite and barite (Anderson et al. 1990). Like the skeleton-bearing dinoflagellates, acantharians, which are extremely abundant in the plankton, are absent from sediments and the fossil record because their skeletons rapidly dissolve upon cell death (Bernstein et al. 1987). Our study reveals that the Acantharia and the polycystine radiolarians are not the only organisms that control the fluxes of strontium and barium in the world's oceans.

There are two possible scenarios for the acquisition of a celestite skeleton by Achradina: (1) an ancestral trait that has been developed independently sometime in the evolution of dinoflagellates, and subsequently lost in all other lineages, and (2) a novel trait that has been acquired, most probably because of a symbiotic relationship with Radiozoa. The first hypothesis implies many function losses, and appears therefore most unlikely. Conversely, the physical proximity of Radiozoa and dinoflagellates may well have favored the second one. Indeed, since the earlier plankton studies, the Radiozoa (Acantharia and Polycystinea) were known to harbor microalgal symbionts, including dinoflagellates
(Anderson 2014). Few of these symbionts have been characterized by morphological and molecular methods (Probert et al. 2014, Yuasa et al. 2016). However, molecular surveys revealed a high diversity of these symbionts (Gast 2006; Gast and Caron 1996, 2001; Dolven et al. 2007). To date, seven clades of dinokaryotic dinoflagellates have been reported as symbionts of acantharians and polycystine radiolarians (Dolven et al. 2007, Decelle et al. 2012, Fig. 2). Undoubtedly more examples will appear in the future. Dinoflagellates have an extraordinary capability to acquire organelles and whole gene clusters from other groups of organisms, and these transfers are even more common when organisms develop a symbiotic relationship (Lin 2011, Wisecaver and Hackett 2011). We suggest that the ancestors of Achradina have developed a symbiotic relationship with some Radiozoan species, and subsequently acquired the genes necessary for $\mathrm{Sr}$ and $\mathrm{Ba}$ deposition.

Acknowledgements. F.G. was supported by the Brazilian Conselho Nacional de Desenvolvimento Científico e Tecnológico (grant no. BJT 370646/2013-14). E.L. was supported by the Swiss SNF project 310003A 143960 .

\section{REFERENCES}

Anderson O. R. (2014) Living together in the plankton: A survey of marine protist symbioses. Acta Protozool. 53: 29-38

Anderson O. R., Perry C. C., Hughes N. P. (1990) Transmission and scanning electron microscopic evidence for cytoplasmic deposition of strontium sulfate crystals in colonial radiolarian. Phil. Trans. R. Soc. B. 329: $81-86$

Bernstein R. E., Feely R. A., Byrne R. H., Lamb M. F., Michaels A. F. (1987) Acantharian fluxes and strontium to chlorinity ratios in the North Pacific Ocean. Science 237: 1490-1494

Decelle J., Siano R., Probert I., Poirier C., Not F. (2012) Multiple microalgal partners in symbiosis with the acantharian Acanthochiasma sp. (Radiolaria). Symbiosis 58: 233-234

Dolven J. K., Lindqvist C., Albert V. A., Bjørklund K. R., Yuasa T., Takahashi O., Mayama S. (2007) Molecular diversity of alveolates associated with neritic north Atlantic radiolarians. Protist 158: $65-76$

Edgar R. C. (2004) MUSCLE: multiple sequence alignment with high accuracy and high throughput. Nucleic Acids Res. 32: 1792-1797

Fensome R. A., Taylor F. J. R., Norris G., Sarjeant W. A. S., Wharton D. I., Williams G. L. (1993) A Classification of Living and Fossil Dinoflagellates. Am. Mus. Nat. Hist., Micropaleontology

Fig. 2. Bayesian phylogenetic tree of dinoflagellate SSU rDNA sequences, based on 1,610 aligned positions. Names in bold represent sequences obtained in this study. The clades containing sequences of the symbionts of acantharians and polycystine radiolarians are highlighted in shaded boxes. Numbers at nodes are bootstrap values (values $<50$ are omitted). The scale bar represents the number of substitutions for a unit branch length. 
special publication number 7. Sheridan Press, Hanover, Pennsylvania

Gast R. J. (2006) Molecular phylogeny of a potentially parasitic dinoflagellate isolated from the solitary radiolarian, Thalassicolla nucleata. J. Eukaryot. Microbiol. 53: 43-45

Gast R. J., Caron D. A. (1996) Molecular phylogeny of symbiotic dinoflagellates from planktonic foraminifera and radiolaria. Mol. Biol. Evol. 13: 1192-1197

Gast R. J., Caron D. A. (2001) Photosymbiotic associations in planktonic foraminifera and radiolaria. Hydrobiol. 461: 1-7

Hall T. A. (1999) BioEdit: a user-friendly biological sequence alignment editor and analysis program for Windows 95/98/NT. Nucleic Acids Symp. Ser. 41: 95-98

Hernández-Becerril D. U., Bravo-Sierra E. (2004) New records of planktonic dinoflagellates (Dinophyceae) from the Mexican Pacific Ocean. Bot. Mar. 47: 417-423

Hollande A., Cachon J., Cachon-Enjumet M. (1962) Mise en évidence par la microscopie électronique, d'une capsule centrale chez divers péridiniens. Considérations sur les affinités entre dinoflagellés et radiolaires. C. R. Hebd. Seances Acad. Sci. 254: 2069-2071

Kiriakoulakis K., Vilas J. C., Blackbird S. J., Aristegui J., Wolff G. A. (2009) Seamounts and organic matter - Is there an effect? The case of Sedlo and Seine seamounts, Part 2. Composition of suspended particulate organic matter. Deep Sea Res. II 56: 2631-2645

Lara E., Mitchell E. A. D., Moreira D., López García P. (2011) Highly diverse and seasonally dynamic protist community in a pristine peat bog. Protist 162: 14-32
Lin S. (2011) Genomic understanding of dinoflagellates. Res. Microbiol. 165: 551-569

López-García P., Rodríguez-Valera F., Pedrós-Alió C., Moreira D. (2001) Unexpected diversity of small eukaryotes in deep-sea Antarctic plankton. Nature 409: 603-607

Miller M. A., Pfeiffer W., Schwartz T. (2010) Creating the CIPRES Science Gateway for inference of large phylogenetic trees. In: Proceedings of the Gateway Computing Environments Workshop (GCE), 1-8, 14 Nov. 2010, New Orleans, LA

Probert I., Siano R., Poirier C., Decelle J., Biard T., Tuji A., Suzuki N., Not F. (2014) Brandtodinium gen. nov. and B. nutricula comb. nov. (Dinophyceae), a dinoflagellate commonly found in symbiosis with polycystine radiolarians. J. Phycol. 55: 388-399

Sournia A. (1986) Atlas du Phytoplancton Marin. Vol. I: Cyanophycées, Dictyochophycées, Dinophycées, Raphidophycées. CNRS, Paris

Stamatakis A., Hoover P., Rougemont J. (2008) A rapid bootstrap algorithm for the RAxML web-servers. Syst. Biol. 75: 758-771

Taylor F. J. R. (1987) The Biology of Dinoflagellates. Blackwell, Oxford

Wisecaver J. H., Hackett J. D. (2011) Dinoflagellate genome evolution. Ann. Rev. Microbiol. 65: 369-387

Yuasa T., Horiguchi T., Mayama S., Takahashi O. (2016) Gymnoxanthella radiolariae gen. et $\mathrm{sp}$. nov. (Dinophyceae), a dinoflagellate symbiont from solitary polycystine radiolarians. J. Phycol. 52: $89-104$

Received on $11^{\text {th }}$ April, 2017; revised on $16^{\text {th }}$ July, 2017; accepted on $16^{\text {th }}$ July, 2017 